\title{
Research of factors influencing the burnout quality inside a biomass combustion chamber
}

\author{
T. Vonžodas*, N. Pedišius**, A. Džiugys**** \\ *Lithuanian Energy Institute, Breslaujos str. 3, 44403 Kaunas, Lithuania, E-mail: Tomas.Vonzodas@lei.lt \\ **Lithuanian Energy Institute, Breslaujos str. 3, 44403 Kaunas, Lithuania, E-mail: Nerijus.Pedisius@lei.lt \\ ***Lithuanian Energy Institute, Breslaujos str. 3, 44403 Kaunas, Lithuania, E-mail: Algis.Dziugys@lei.lt \\ cross $^{\text {ref }}$ http://dx.doi.org/10.5755/j01.mech.23.1.13960
}

\section{Introduction}

Use of renewable energy sources in the European Union EU-28 reached $15 \%$ (in gross final energy consumption) in 2013 [1]. On the one hand, wood and wood waste is a very important renewable energy source. Today, wood and its waste accounts for almost $50 \%$ of the EU-28 renewable energy production [2-3].

Lithuania reached the 2020 targets of the European Commission to produce $23 \%$ of energy from renewable energy sources as early as in 2013 [1]. The most significant renewable energy potential in Lithuania also includes biofuel, especially wood and its waste. The analysis of use structure of fuelwood and agricultural waste [4] shows that in 2014 most of it (46.9\%) was used in households. 41.3 per cent of fuelwood and agricultural waste is used in boilers of district heating plants and power plants. Therefore, efficiency and minimal emissions of boilers used in households are very important.

Biofuel in residential buildings should be burnt in two ways, one of which is biofuel burnt in stoves with heat radiated directly into the room. The other way is burning biofuel in boilers with a water circuit, with hot water supplied into the pipework under the house. Therefore, burning of biofuel in residential buildings can be done in simple furnaces, as well as in well controlled boilers, such as in wood pellet boilers. However, high emissions from incomplete fuel combustion in small-scale appliances like wood stoves and fireplaces have been reported in several countries [4]. Thus pollutants are emitted in high quantities. Particle concentrations of stoves or fireplaces can exceed those of well controlled boilers by up to 50 times. Therefore it very important to pay attention to the type of biofuel burning appliance used, in addition to appreciation of the face that use of biofuel decreases emissions of greenhouse gases instead of evaluation. It is known that modern biomass burning systems have reached such technological level, that relatively low levels of pollutants are emitted [5].

For purposes of this research the most common type of combustion chamber was selected, with internal volume of $0.06 \mathrm{~m}^{3}$ and inner lining with vermiculite. Air is supplied into the chamber through three channels. The first is used for air supply during ignition of fuel, thereafter this duct is closed. The second channel is used for primary air supply, it flows around the fuel maintaining the combustion process, this air also flows at the door glass thus reducing sooting of the glass. The amount of this air supply can be adjusted using a damper. The third air supply is through the air ducts at the back wall. This air is used in secondary combustion. Description of such structure being typical is also given by the authors [6].

As the fuel burns, many physical and chemical processes take place simultaneously in the combustion chamber. These processes include: drying and heating of fuel, separation of volatile compounds, flaming of pyrolysis products and combustion of coal. Burning of biomass produces carbon dioxides, carbon monoxides, water vapour, ash, sulphur oxides, unburnt hydrocarbons, nitrogen oxides, solid particles [7-8].

Formation of combustion emissions is most influenced by the fuel properties and design parameters of furnace (e.g., excess air, particle size, dimensions of the combustion chamber, etc.). The combustion air is usually supplied by way of natural circulation, thus it heavily depends on environmental conditions and furnace configuration [9]. Authors have confirmed this fact by determining that fine particle mass emission factors from wood stoves are significantly lower than those from fireplaces [10].

With tightening of requirements for emissions of combustion devices, increasing attention is paid for research of reduction of emission levels. Therefore, it is important to be able to evaluate amounts of pollutants released into the atmosphere from these individual sources [11]. Since a significantly high emission level is reached, the focus is not only on the main factors influencing the combustion quality, but also on the minor factors, since their influence on reduction of emission levels becomes increasingly important [8]. For this reason, this research seeks to find out how the combustion quality is influenced by the structural elements of the combustion chamber, such as the thermal insulation layer of the combustion chamber and the position of secondary air intake.

\section{Experimental procedure}

\subsection{Subject of the experiment}

The scheme of the combustion chamber used in the research is given in Fig. 1. The main parts of the stove are the following: combustion chamber with grate at the bottom, through which the ash falls into the ashbin; ignition and primary air adjustment dampers. There are three air supply zones inside the stove. The air passes through the first zone and the grate into the combustion chamber and is instantly used in the combustion process. The purpose of this air is to be used during the first lighting and for faster ignition of fuel after feeding a new dose of fuel, therefore this air supply is shut two minutes after loading a new dose of fuel. Air from the second zone is supplied 
immediately at the door glass, the amount of this air supply can be adjusted using a damper. It is used as the main air supply for maintaining the combustion of fuel and for protecting the glass from sooting. The third air supply takes place through nine air ducts of $7 \mathrm{~mm}$ diameter at the back wall. It is used for secondary combustion, thus hereinafter referred to as secondary air. Temperature of the combustion chamber can be adjusted using the thermocouple at the centre of the combustion chamber.

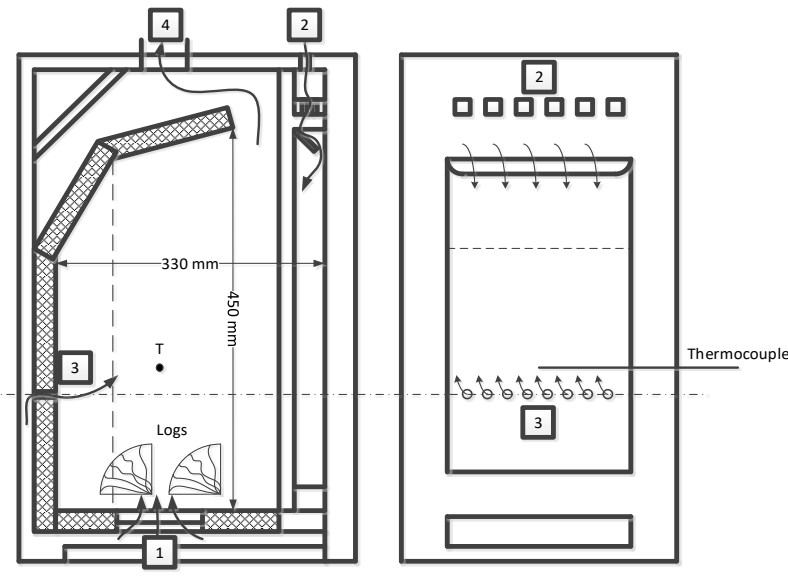

Fig. 1 Scheme of the combustion chamber: 1 - ignition air; 2 - primary air; 3 - secondary air; 4 - flue gas outlet

\subsection{Experimental procedure and condition}

This research uncovered the influence of two structural elements on operating parameters of the combustion chamber; these are:

1. influence of internal materials combustion chamber of different properties;

2. influence of the position of the secondary air channel.

Concentrations of gases emitted from the combustion chamber, the efficiency coefficient and other parameters depend on the structural elements of the combustion chamber. One of the most important elements is the internal thermal insulation layer of the combustion chamber, which is used to maintain the optimal temperature of 700$800^{\circ} \mathrm{C}$ inside the chamber. It is difficult to maintain such temperature inside the stove due to periodical reloading of fuel, heat dissipation through cold surfaces, such as glass, and due to supply of cold air into the chamber. Internal walls of the combustion chamber used for research were made from different ratios of $\mathrm{Si}, \mathrm{Al}, \mathrm{Mg}$, and $\mathrm{K}$ oxides. Properties of these ceramic materials are presented in Table 1. Even though the difference of density of these materials can be twofold, but the difference of specific heat is only $6 \%$, and the heat conductivity of vermiculite $\mathrm{V} 1$ at $600^{\circ} \mathrm{C}$ is $31 \%$ lower. Thickness of materials used was the same in both cases.

Table 1

Properties of the used vermiculite

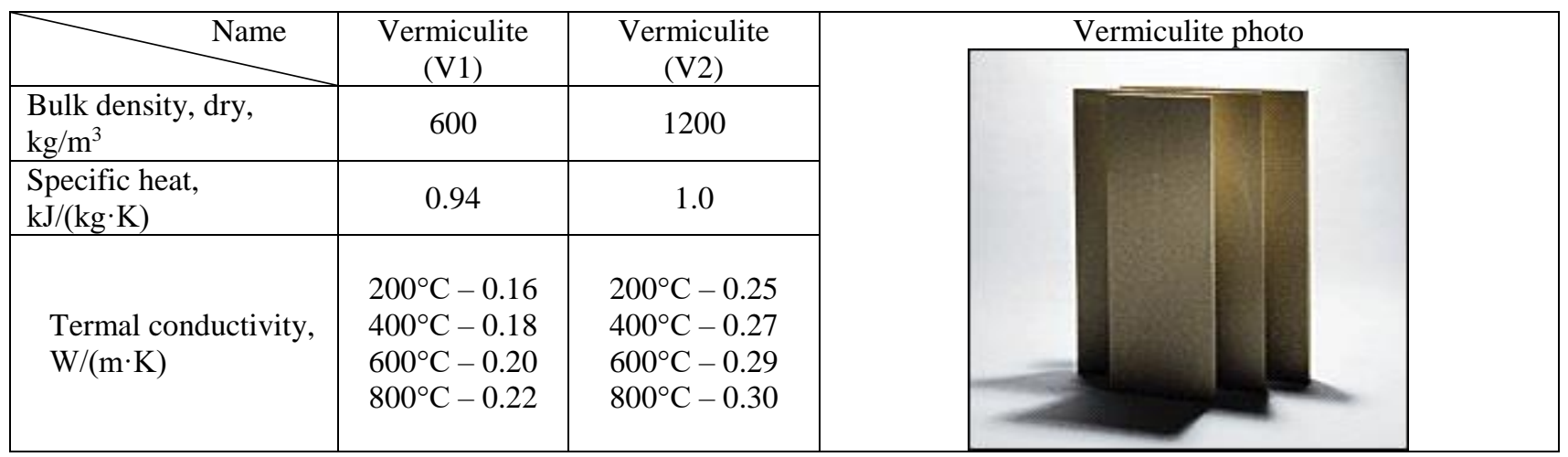

The second objective was to investigate another important structural element - position of the secondary air intake - which has a significant impact on combustion quality. In this structure the secondary air is drawn through the channels at the back wall due to the resulting draught in the combustion device. There is no possibility to adjust the amount of this air with any damper. Therefore, correct position of the intake is very important, since it will be the determining factor for appropriate mixing of combustion products and the supplied air, and for the appropriate duration of stay of the mixture in the combustion chamber.

Three positions of air intake openings were selected for the research. In the first case, secondary air channels were installed at the height ratio of the chamber $\mathrm{X}$ and the channels $\mathrm{H} 1$ of 2.7 , in the second case -2.3 , and in the third case -2 . In all cases the number of channels was the same, i. e. 9 channels, with the diameter $(7 \mathrm{~mm})$ and the spacing between them, as well as the position in relation to the side wall remaining the same.

European standards describe tests of solid fuel furnaces, therefore tests were based on standard
LST EN 13240 (Room heaters fired by solid fuel - Requirements and test methods) [11]. The combustion chamber was heated at the beginning of the test, a fuel bed was prepared, so that at the beginning of testing all surfaces would be heated up to operating temperatures, thus ensuring similar conditions for all tests. Later tests were performed for optimum adjustment of air flows. Thereafter, having set fixed combustion chamber parameters, tests were carried out with various structural elements. Tests with both different insulating materials of the chamber and different secondary air intake position, were carried out at the same conditions and settings. At least six full fuel combustion cycles were carried out with every modified structural element. Three test cycles with the most similar values were selected for calculations, thus eliminating random deviations. Duration of combustion period heavily depends on mass on form of loaded fuel, therefore all tests were carried out with the same amount and form of fuel, i. e. two pieces of fuel-wood with a gap of $1 \mathrm{~cm}$ between them were used in all tests. 


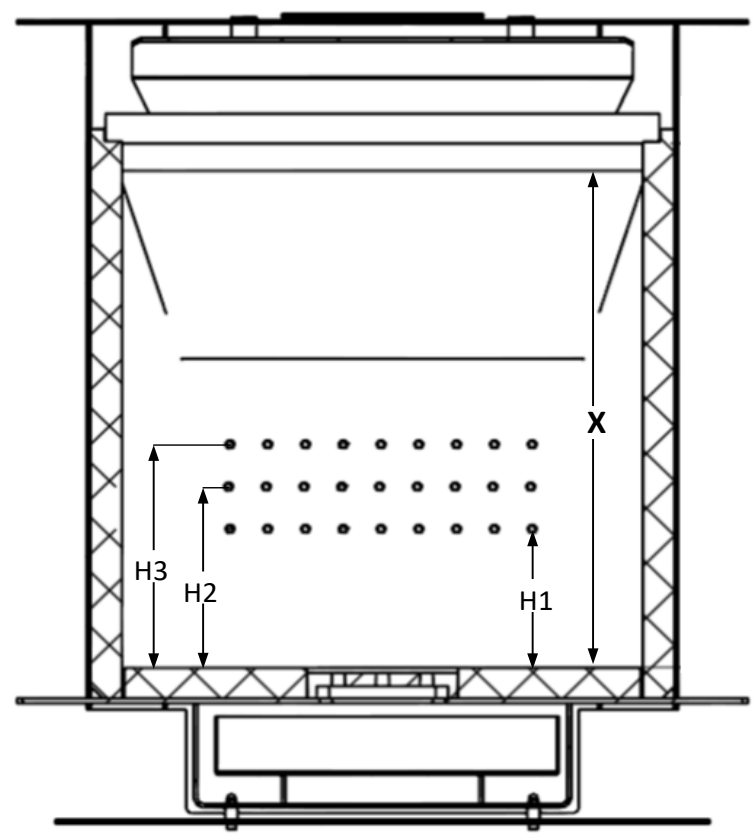

Fig. 2 Layout of the secondary air channels, X/H1 - 2.7, $\mathrm{X} / \mathrm{H} 2-2.3, \mathrm{X} / \mathrm{H} 3-2$

\subsection{Fuel used for testing}

For purposes of this study, ash wood was used in all tests. Ash wood is the most commonly used firewood. The calorific value of the fuel used was measured by burning the fuel in the bomb calorimeter, the main elements carbon, oxygen, hydrogen, nitrogen and sulphur - were measured by gas chromatography. Ash content was determined by burning the sample at the temperature of $550^{\circ} \mathrm{C}$, and the moisture content was determined by drying at the temperature of $105^{\circ} \mathrm{C}$. The results obtained are given in Table 2 . The measured parameters give statistically reliable correlation with the results presented in the article [12].
Table 2

Ultimate and proximate analysis of wood fuel used

\begin{tabular}{|l|c|r|c|}
\hline \multicolumn{1}{|c|}{ Parameter } & Unit & Value & $\begin{array}{c}\text { The expanded } \\
\text { uncertainty, \% }\end{array}$ \\
\hline Moisture & $\%$ & 10,4 & 0,20 \\
\hline Ash & $\%$ & 1,4 & 0,38 \\
\hline Low heating & $\mathrm{MJ} / \mathrm{kg}$ & 16,03 & 1,31 \\
\hline Carbon $(\mathrm{C})$ & $\%$ & 49,1 & 0,58 \\
\hline Oxygen $(\mathrm{O})$ & $\%$ & 42,8 & 0,34 \\
\hline Hydrogen $(\mathrm{H})$ & $\%$ & 5,8 & 0,33 \\
\hline Nitrogen $(\mathrm{N})$ & $\%$ & 0,3 & 0,28 \\
\hline Sulphur $(\mathrm{S})$ & $\%$ & 0,12 & 0,20 \\
\hline
\end{tabular}

\subsection{Determination of flue gas composition}

During this test all parameters were measured every 20 seconds, the scheme of measurements is given in Fig. 3. The components $\left(\mathrm{CO}, \mathrm{CO}_{2}, \mathrm{NO}_{\mathrm{x}}, \mathrm{SO}_{2}, \mathrm{HCl}\right.$, total $\mathrm{C}_{\mathrm{x}} \mathrm{H}_{\mathrm{y}}$ and different VOC's) were measured at the height of $1.2 \mathrm{~m}$ above the furnace using Fourier transform infrared (FTIR) spectrometer with a heated probe. $\mathrm{NO}_{\mathrm{x}}$ concentrations were calculated as a sum of measured $\mathrm{NO}$ and $\mathrm{NO}_{2}$ concentrations. Particulate matter (PM) was measured employing the isokinetic measuring method. The measuring probe was installed at the centre of the flue channel and sampling was carried out for 30 minutes using a filter, which collects $99.8 \%$ of smoke particles. The filter was dried at a temperature of $160^{\circ} \mathrm{C}$ one hour before and one hour after the measurement, and then weighed to an accuracy of $\pm 0.1 \mathrm{mg}$. Balance was used to determine the exact time when the entire amount of loaded fuel has burnt. Balance can also be used to track the combustion speed of fuel at different combustion phase. Concentration measurements of all emitted components were carried out by measuring the concentrations at parts per million (ppm).

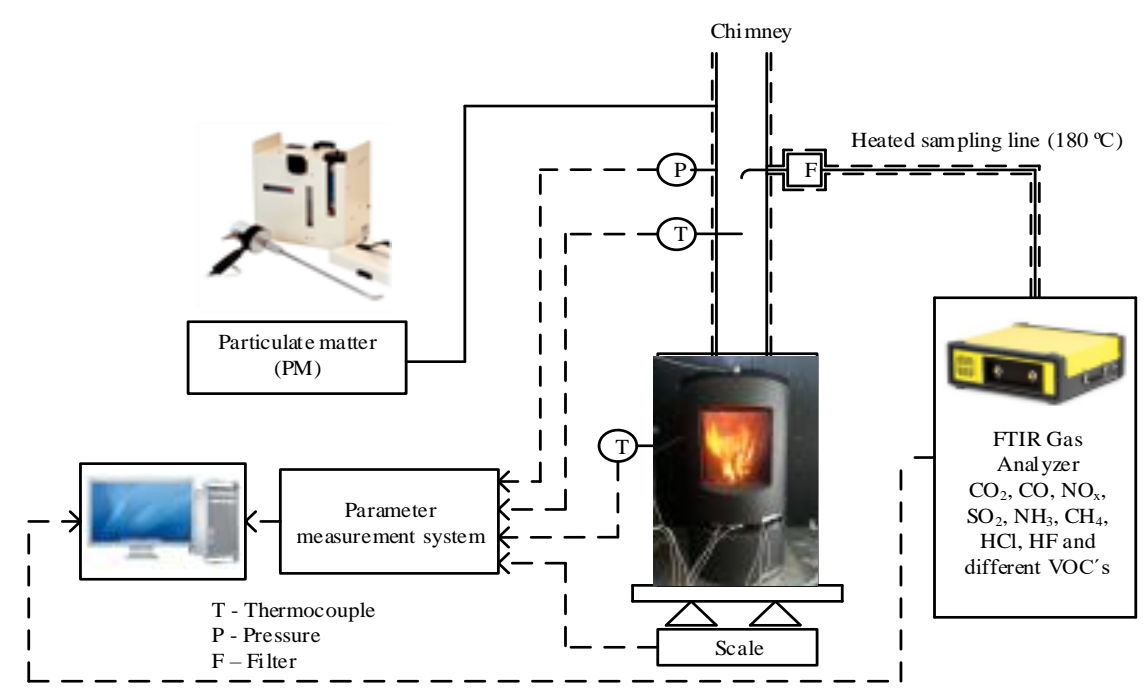

Fig. 3 Principle measurement scheme

\subsection{Calculation of efficiency and excess air coefficient}

The amount of heat produced in the furnace is conducted into the environment at the time of combustion by way of natural convection and radiation from the hot surfaces of the furnace and the flue. As part of this test, the coefficient of efficiency was estimated by the indirect method. This calculation was carried out by subtracting the losses of heat with the discharged smoke, the losses of chemically incomplete combustion and losses due to incomplete combustion from $100 \%$. Thus the coefficient of efficiency is calculated by formula: 


$$
\eta=100-\left(q_{a}+q_{b}+q_{r}\right), \%
$$

Here are the heat losses of smoke [13][14]:

$$
\begin{gathered}
Q_{a}=\left(t_{a}-t_{r}\right) \times\left[\begin{array}{l}
{\left[\frac{C_{p m d}\left(C-C_{r}\right)}{0.536\left(\mathrm{CO}+\mathrm{CO}_{2}\right)}\right]+} \\
+\left[\frac{C_{p m \mathrm{H}_{2} \mathrm{O}} \times 1.224 \times(9 \times H+W)}{100}\right]
\end{array}\right], \frac{\mathrm{kJ}}{\mathrm{kg}} ;(2) \\
q_{a}=100 \times \frac{Q_{a}}{H_{U}}, \%
\end{gathered}
$$

where $H_{u}$ - calorific value of fuel heat losses due to incomplete chemical combustion:

$$
\begin{gathered}
Q_{b}=12644 \times \mathrm{CO} \times \frac{\left(C-C_{r}\right)}{\left(0.536 \times\left(\mathrm{CO}_{2}+\mathrm{CO}\right) \times 100\right)}, \mathrm{kJ} / \mathrm{kg} ; \\
q_{b}=100 \times \frac{Q_{b}}{H_{U}}, \%
\end{gathered}
$$

and losses due to incomplete combustion in fuel ashes:

$$
Q_{r}=335 \times \frac{b R}{100}, \mathrm{~kJ} / \mathrm{kg},
$$

here $b$ - combustible fuel residue in ashes (\%); $R$ - amount of fuel fallen through the grate $(\%)$.

$$
q_{r}=100 \times \frac{Q_{r}}{H_{U}}, \% .
$$

Then the nominal power of the device is calculated by the fuel amount burnt within an hour $(B)$, the calorific value of fuel $\left(H_{u}\right)$ and coefficient of efficiency $(\eta)$, by formula [13][14]:

$$
P=\frac{\left(\eta B H_{U}\right)}{100 \times 3600}, \mathrm{~kW} .
$$

Excess air coefficient is calculated by formula:

$$
\lambda=\frac{\mathrm{CO}_{2 \max }}{\mathrm{CO}_{2}}
$$

and $\mathrm{CO}_{2 \max }$ is calculated by formula:

$$
\mathrm{CO}_{2 \max }=\frac{1}{\left(1+m_{s}+A \times\left(\frac{79}{21}\right)\right)} \times 100 \%,
$$

here $m_{s}$ - amount of sulphur, mol; $A$ - stoichiometric factor, $\mathrm{mol} / \mathrm{mol}$.

\section{Results}

3.1. Dependency of combustion chamber parameters on different vermiculites V1 and V2

Figs. 4-9 display the effect of different materials of the internal chamber on temperatures of $\mathrm{CO}_{2}, \mathrm{CO}, \mathrm{C}_{\mathrm{x}} \mathrm{H}_{\mathrm{y}}$, $\mathrm{NO}_{\mathrm{x}}$, smoke and furnace, also the average values of all tests are presented in Table 3. Table 3 also includes average values of other resulting components, such as sulphur dioxide $\left(\mathrm{SO}_{2}\right)$, ammonia $\left(\mathrm{NH}_{3}\right)$, hydrogen chloride $(\mathrm{HCl})$, hydrogen fluoride $(\mathrm{HF})$, formaldehyde $(\mathrm{HCHO})$, methane $\left(\mathrm{CH}_{4}\right)$ and other unburned hydrocarbons $\left(\mathrm{C}_{\mathrm{x}} \mathrm{H}_{\mathrm{y}}\right)$ and particulate matter (PM). Other parameters, determined and calculated during tests are presented in Table 4. Similar test conditions were maintained during these tests, also, three combustion intervals were selected to achieve the most precise results.

The furnace combustion process can be divided into three combustion phase: ignition phase, main combustion phase and final combustion (burn-up) phase. At the ignition phase, the $\mathrm{CO}_{2}$ concentration in smoke reaches the peak value, since the very surface is burning are the initial combustion phase and volatile materials are discharged at a high flow from deeper fuel layers [16]. Also, the temperature of the combustion chamber at the ignition phase has dropped, as seen in Fig. 9. While the oxygen $\left(\mathrm{O}_{2}\right)$ concentration and the furnace temperature is low, the combustion conditions are unsuitable, therefore high concentrations of unburnt components such as $\mathrm{CO}, \mathrm{C}_{\mathrm{x}} \mathrm{H}_{\mathrm{y}}$, etc. are detected. As soon as the combustion conditions stabilize, the main combustion phase begins. This phase is characterised by sufficiently stable $\mathrm{O}_{2}$ concentration and high temperature of the combustion chamber, which ensures suitable combustion conditions. Concentrations of unburnt components resulting in this phase are significantly lower compared to the ignition phase. At the final combustion phase the $\mathrm{O}_{2}$ concentration and the temperature of the combustion chamber begins to decrease, the excess air ratio $(\lambda)$ in this phase can fluctuate from 2 as high as up to 4 . For this reason, the concentrations of remaining unburnt components in the emitted smoke begins to increase, with the exception of $\mathrm{NO}_{\mathrm{x}}$, since the entire amount of nitrogen in the fuel is already oxidised, therefore its concentration does not increase in the final burn-up phase. Fig. 5, the same was noticed by authors of the article [11].

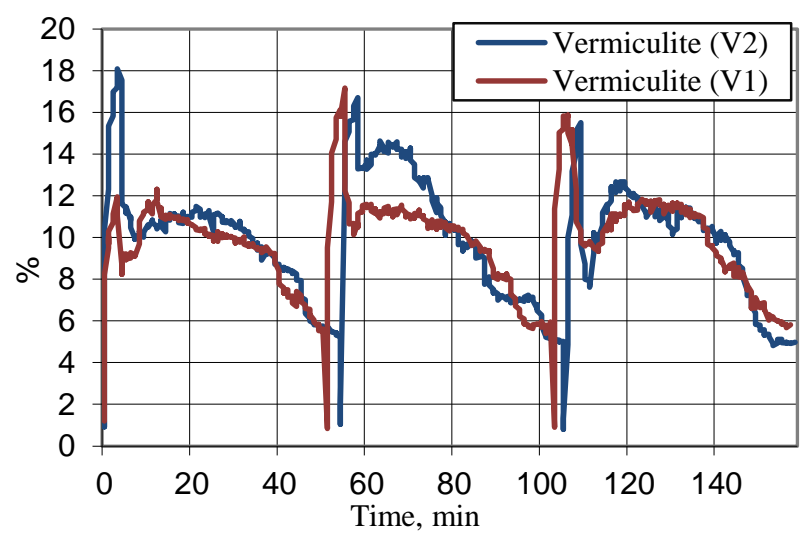

Fig. 4 Comparison of concentrations of $\mathrm{CO}_{2}$ by using vermiculites V1 and V2 of different thermal conductivity

Use of vermiculite $\mathrm{V} 1$ causes a decrease of $\mathrm{CO}$, total $\mathrm{C}_{\mathrm{x}} \mathrm{H}_{\mathrm{y}}, \mathrm{NH}_{3}, \mathrm{HCl}, \mathrm{CH}_{4}$, and other hydrocarbons, and an increase of $\mathrm{NO}_{\mathrm{x}}$ and $\mathrm{HCN}$. The same trend was also determined by noticed by authors [17].

One of the most important factors for the coefficient of efficiency of a furnace is the excess air ratio, as stated by authors [11]. Since the air flows of the furnace 
used in the tests are not automatically controlled, the excess air ratio varies at a very wide range from 1.2 to as much as almost 4, which heavily influences losses in smoke.

Since the chart of concentrations of $\mathrm{NO}_{\mathrm{x}}$ in Fig. 7 shows that peak values of concentrations form at the beginning, and is later slowly decreasing as the combustion draws to the end, however, as the authors have noted [16], the $\mathrm{NO}_{\mathrm{x}}$ emission factors are dependent on the phase of combustion, that is, whether it is flaming or smouldering, although the effect is not large. For this reason, the $\mathrm{NO}_{\mathrm{x}}$ decrease seen in the chart is more influenced by fuel combustion speed, which decreases at the end of combustion.

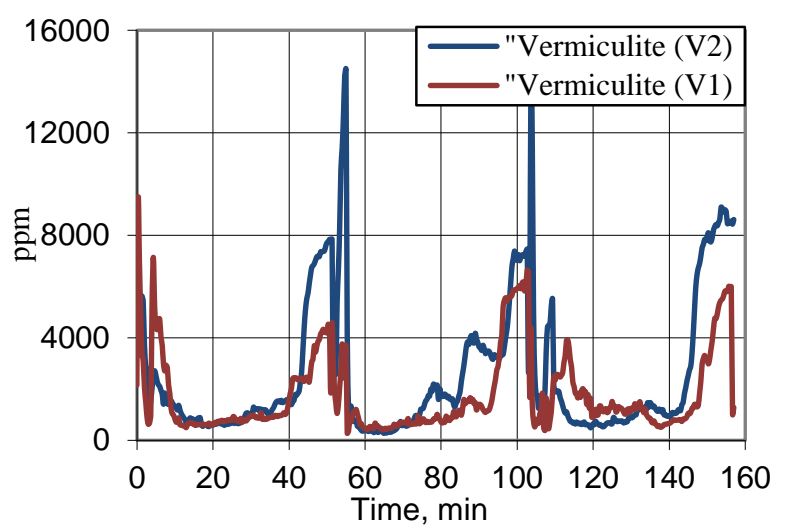

Fig. 5 Comparison of concentrations of $\mathrm{CO}$ by using vermiculites V1 and V2 of different thermal conductivity

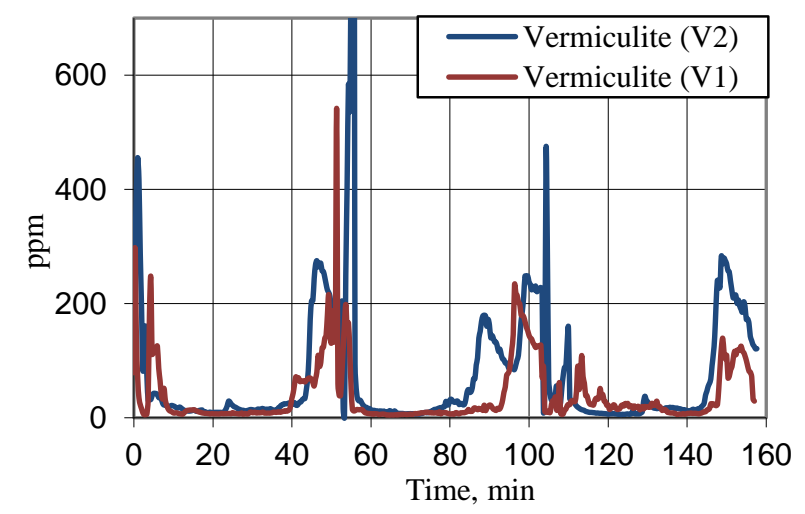

Fig. 6 Comparison of concentrations of $\mathrm{C}_{\mathrm{x}} \mathrm{H}_{\mathrm{y}}$ by using vermiculites $\mathrm{V} 1$ and $\mathrm{V} 2$ of different thermal conductivity

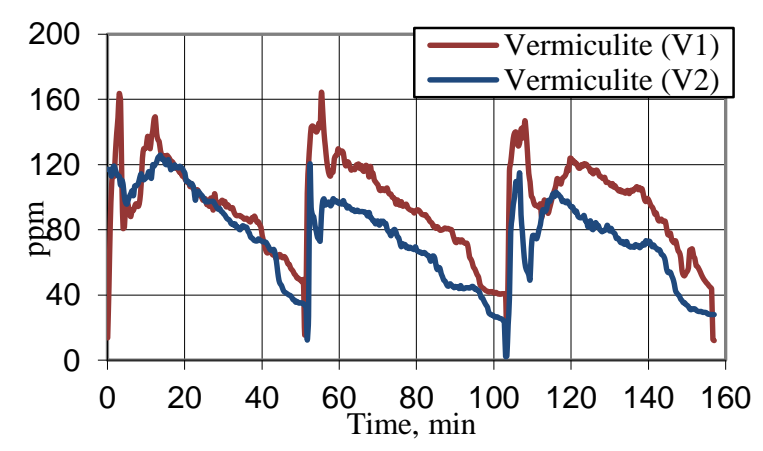

Fig. 7 Comparison of concentrations of $\mathrm{NO}_{\mathrm{y}}$ by using vermiculites V1 and V2 of different thermal conductivity
When using vermiculite $\mathrm{V} 1$, which has the heat conductivity of $0.2 \mathrm{~kJ} /(\mathrm{kg} \mathrm{K})$ and which is $31 \%$ lower than $\mathrm{V} 2$, the difference of chamber temperatures in these two cases is not so large as the chamber temperature when using V1 vermiculate is only approximately 5\% higher. However, as noted other authors have noted [5], the temperature of the combustion chamber has significant influence on the speed of reaction, which is even exponential [18], however there are many other factors, which determines the quality of combustion. For this reason in can be stated, that higher temperature at the combustion chamber only partially contributes to lower formation of pollutants. When using vermiculate $\mathrm{V} 1$, the amount of oxygen $\left(\mathrm{O}_{2}\right)$ in smoke is higher, although only slightly, therefore compounding the increase of the combustion chamber temperature and the higher excess air ratio results efficiency, which is lower than when using vermiculite V2, which produces higher amounts of unburnt pollutants.

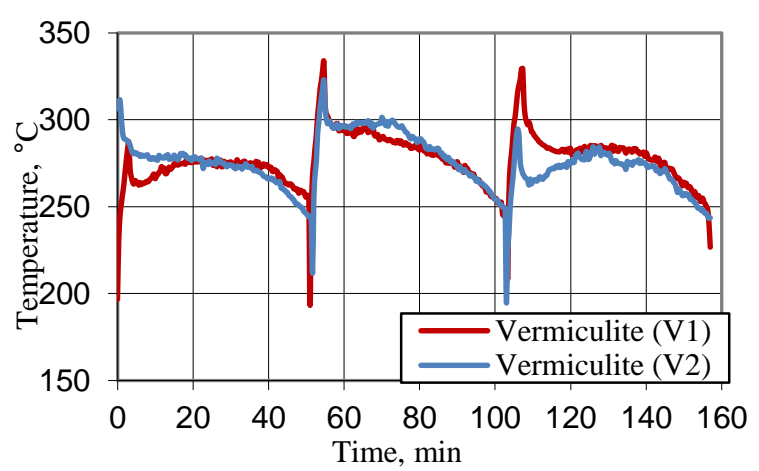

Fig. 8 Change of smoke temperatures using vermiculites $\mathrm{V} 1$ and $\mathrm{V} 2$ of different thermal conductivity

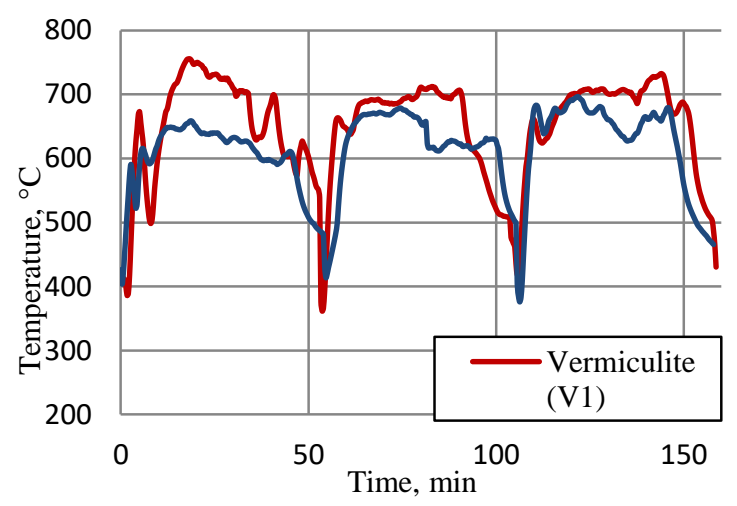

Fig. 9 Temperature of the combustion chamber using vermiculites V1 and V2 of different thermal conductivity

Therefore the mixing of the combustion air with the flue gases is the most important factor for achieving improved burnout, also the furnace temperatures play an important role. The flue gas should have enough residence time at temperatures $>800^{\circ} \mathrm{C}$ in order to complete the oxidation reactions, which means, that it is of advantage not or only moderately to cool the part of the secondary combustion chamber where the main burnout [5] takes place.

The $\mathrm{SO}_{2}$ emission factor fully depends on content of sulphur in the biofuels and is not significantly influenced by choice of an appliance or way of its operation. They are generally very low and it is typical that the agricultural fuels show higher content of combustible sulphur compared to wooden based biofuels [16]. 
Concentration results of emitted pollutants

\begin{tabular}{|c|c|c|c|c|}
\hline Components & Unit & $\begin{array}{l}\text { Vermiku- } \\
\text { lite (V1) }\end{array}$ & $\begin{array}{c}\text { Vermiku- } \\
\text { lite } \\
\text { (V2) }\end{array}$ & $\begin{array}{c}\text { The ex- } \\
\text { panded } \\
\text { uncer- } \\
\text { tainty, \% }\end{array}$ \\
\hline $\mathrm{CO}_{2}$ & $\%$ & 9,73 & 9,91 & 2,00 \\
\hline $\mathrm{O}_{2}$ & $\%$ & 10,72 & 10,39 & 2,00 \\
\hline $\mathrm{CO}$ & ppm & 1793,71 & 2541,25 & 2,02 \\
\hline $\mathrm{NO}_{\mathrm{x}}$ & $\mathrm{ppm}$ & 95,02 & 76,04 & 2,52 \\
\hline Sulfur dioxide $\mathrm{SO}_{2}$ & ppm & 3,50 & 4,70 & 4,54 \\
\hline Ammonia $\mathrm{NH}_{3}$ & ppm & 2,81 & 5,93 & --- \\
\hline \begin{tabular}{|l}
$\mathrm{C}_{\mathrm{x}} \mathrm{H}_{\mathrm{y}}$ (Total hydrocar- \\
bons by Gasmet)
\end{tabular} & ppm & 115,16 & 212,93 & 4,04 \\
\hline Hydrogen chloride $\mathrm{HCl}$ & $\mathrm{ppm}$ & 0,49 & 0,87 & --- \\
\hline Methane $\mathrm{CH}_{4}$ & ppm & 81,05 & 152,35 & --- \\
\hline Ethane $\mathrm{C}_{2} \mathrm{H}_{6}$ & $\mathrm{ppm}$ & 0,66 & 0,75 & --- \\
\hline Propane $\mathrm{C}_{3} \mathrm{H}_{8}$ & $\mathrm{ppm}$ & 1,55 & 3,12 & $\begin{array}{c}-- \\
\end{array}$ \\
\hline Ethylene $\mathrm{C}_{2} \mathrm{H}_{4}$ & ppm & 6,74 & 10,37 & --- \\
\hline Hexane $\mathrm{C}_{6} \mathrm{H}_{14}$ & ppm & 1,04 & 0,71 & --- \\
\hline Formaldehyde $\mathrm{CHOH}$ & ppm & 6,75 & 10,15 & --- \\
\hline Acetylene $\mathrm{C}_{2} \mathrm{H}_{2}$ & ppm & 3,37 & 6,93 & --- \\
\hline Acetic acid $\mathrm{C}_{2} \mathrm{H}_{4} \mathrm{O}_{2}$ & ppm & 6,18 & 6,45 & --- \\
\hline Methanol $\mathrm{CH}_{4} \mathrm{O}$ & $\mathrm{ppm}$ & 0,92 & 1,12 & --- \\
\hline Acetaldehyde $\mathrm{C}_{2} \mathrm{H}_{4} \mathrm{O}$ & ppm & 0,59 & 0,55 & --- \\
\hline Benzene $\mathrm{C}_{6} \mathrm{H}_{6}$ & ppm & 0,62 & 2,16 & --- \\
\hline Styrene $\mathrm{C}_{8} \mathrm{H}_{8}$ & ppm & 3,06 & 1,93 & --- \\
\hline Ethanol $\mathrm{C}_{2} \mathrm{H}_{6} \mathrm{O}$ & ppm & 1,51 & 13,09 & --- \\
\hline Propene $\mathrm{C}_{3} \mathrm{H}_{6}$ & ppm & 1,35 & 1,95 & --- \\
\hline Propionaldehyde $\mathrm{C}_{3} \mathrm{H}_{6} \mathrm{O}$ & ppm & 0,13 & 0,49 & --- \\
\hline Acrolein $\mathrm{C}_{3} \mathrm{H}_{4} \mathrm{O}$ & $\mathrm{ppm}$ & 0,55 & 1,28 & --- \\
\hline Formic acid $\mathrm{CH}_{2} \mathrm{O}$ & ppm & 0,59 & 1,20 & --- \\
\hline Hydrogen cyanide $\mathrm{HCN}$ & ppm & 7,11 & 6,01 & --- \\
\hline PM & $\begin{array}{l}13 \% \mathrm{O}_{2}, \\
\mathrm{mg} / \mathrm{Nm}^{3}\end{array}$ & 31,1 & 32,5 & 4,96 \\
\hline
\end{tabular}

The $\mathrm{HF}$ and $\mathrm{C}_{7} \mathrm{H}_{8}$ gaseous compounds were not found at quantities exceeding detection limits.

Concentrations of particulate matter remained at a similar level at approximately $31 \mathrm{mg} / \mathrm{Nm}^{3}$, since combustion conditions in both cases are quite similar, and the PM concentrations are highly influenced by the fuel itself, which was noticed by authors [19], since similar fuel was used in both of these tests, therefore the concentrations are very close.

The obtained results show that use of materials of different thermal conductivity for internal walls of the combustion chamber, cause different concentrations of $\mathrm{CO}$ and $\mathrm{C}_{\mathrm{x}} \mathrm{H}_{\mathrm{y}}$ produced in the combustion products. Use of vermiculate $\mathrm{V} 1$ of lower thermal conductivity caused a decrease of $\mathrm{CO}$ concentration of $30 \%$, and a decrease of $\mathrm{C}_{\mathrm{x}} \mathrm{H}_{\mathrm{y}}$ concentration by half. Similar performance of $\mathrm{CO}$ and $\mathrm{C}_{\mathrm{x}} \mathrm{H}_{\mathrm{y}}$ components during combustion was also determined by authors [17]. Formation of these components highly depends on the temperature and appropriate mixing with quantities of air, since different vermiculate should not change mixing conditions, therefore it can be concluded, that decrease of these components is determined by the increased combustion chamber temperature, since use of vermiculite V1 of lower thermal conductivity results in an increase of temperature of $33^{\circ} \mathrm{C}$ in the combustion chamber. However, the increase of the temperature of combustion chamber causes increased generation of "thermal" or "rapid" nitrogen oxides. Thermal oxides are produced due to flame temperature - a prerequisite for oxidation of air nitrogen is presence of atomic oxygen. Oxygen molecule can dissociate into atomic oxygen, and the atomic oxygen reacts with the nitrogen molecule, producing nitrogen oxides: $\mathrm{N}_{2}+\mathrm{O} \leftrightarrow \mathrm{NO}+\mathrm{N}$. Rapid nitrogen oxides are produced due to incomplete reaction of radicals of combustion products of hydrocarbons with nitrogen molecules. However, since the main source of production of nitrogen oxides is nitrogen present in fuel, since separation of nitrogen atoms from fuel compounds needs 1.5 to 4 times less energy than dissociation of oxygen molecules, therefore production of fuel nitrogen takes place at low temperatures [20]. Regularities of formation of nitrogen oxides are reflected in the obtained results. If the vermiculate has lower density, formation of thermal and rapid nitrogen oxides have higher influence, therefore the total amount of nitrogen oxides increases by $27 \%$.

Table 4

Test results

\begin{tabular}{|l|c|c|c|c|}
\hline $\begin{array}{c}\text { Measured and } \\
\text { calculated param- } \\
\text { eters }\end{array}$ & Unit & $\begin{array}{c}\text { Vermikulite } \\
\text { (V1) }\end{array}$ & $\begin{array}{c}\text { Vermikulite } \\
\text { (V2) }\end{array}$ & $\begin{array}{c}\text { The ex- } \\
\text { panded } \\
\text { uncertain- } \\
\text { ty, \% }\end{array}$ \\
\hline Efficiency & $\%$ & 77,63 & 77,82 & $2,62 \%$ \\
\hline $\begin{array}{l}\text { Thermal losses in } \\
\text { flue gas }\end{array}$ & $\%$ & 20,66 & 20,02 & --- \\
\hline Chemical losses & $\%$ & 1,21 & 1,66 & --- \\
\hline $\begin{array}{l}\text { Heat losses due } \\
\text { to unburnt con- } \\
\text { stituents }\end{array}$ & $\%$ & 0,5 & 0,5 & --- \\
\hline $\begin{array}{l}\text { Nominal heat } \\
\text { output }\end{array}$ & $\mathrm{kW}$ & 6,06 & 6,04 & $2,70 \%$ \\
\hline $\begin{array}{l}\text { Flue gas tem- } \\
\text { perature }\end{array}$ & ${ }^{\circ} \mathrm{C}$ & 281,2 & 275,6 & $1,4^{\circ} \mathrm{C}$ \\
\hline $\begin{array}{l}\text { combustion } \\
\text { chamber temper- } \\
\text { ature }\end{array}$ & ${ }^{\circ} \mathrm{C}$ & 645,6 & 612,6 & $1,8^{\circ} \mathrm{C}$ \\
\hline Draft & $\mathrm{Pa}$ & 11,2 & 11,5 & $2 \mathrm{~Pa}$ \\
\hline The test duration & $\mathrm{min}$ & 155,7 & 157,3 & --- \\
\hline Fuel amount & $\mathrm{kg}$ & 4,68 & 4,69 & $12 \mathrm{~g}$ \\
\hline Fuel consumption & $\mathrm{kg} / \mathrm{h}$ & 1,81 & 1,79 & --- \\
\hline
\end{tabular}

3.2. Dependency of emissions on different various positions of secondary air intake

The second objective was to determine which position of the secondary air intake is the most suitable. Three positions of secondary air intake were selected, as seen in Fig. 2, all other parameters were maintained constant. The average values of components resulting during the test at different temperatures of secondary air channels are given in Table 5. All other test parameters, identified and calculated when changing the position of secondary air intake, are presented in Table 6. 
Concentrations of emissions at various positions of secondary air intake channels

\begin{tabular}{|c|c|c|c|c|c|}
\hline Components & Unit & $\mathrm{X} / \mathrm{H} 1$ & $\mathrm{X} / \mathrm{H} 2$ & $\mathrm{X} / \mathrm{H} 3$ & $\begin{array}{l}\text { The ex- } \\
\text { panded } \\
\text { uncer- } \\
\text { tainty, \% }\end{array}$ \\
\hline Carbon dioxide $\mathrm{CO}_{2}$ & $\%$ & 10,3 & 9,9 & 9,6 & 2,00 \\
\hline Oxygen $\mathrm{O}_{2}\left(\mathrm{ZrO}_{2}\right)$ & $\%$ & 10,1 & 10,4 & 10,9 & $\overline{---}$ \\
\hline Carbon monoxide $\mathrm{CO}$ & $\mathrm{ppm}$ & 2067 & 1547 & 1990 & 2,02 \\
\hline Nitrogen dioxides $\mathrm{NO}_{\mathrm{x}}$ & $\mathrm{ppm}$ & 92 & 96 & 90 & 2,52 \\
\hline Sulfur dioxide $\mathrm{SO}_{2}$ & $\mathrm{ppm}$ & 4,5 & 2,9 & 3,5 & 4,54 \\
\hline Ammonia $\mathrm{NH}_{3}$ & $\mathrm{ppm}$ & 6,7 & 3,4 & 7,3 & --- \\
\hline Total hydrocarbons $\mathrm{C}_{\mathrm{x}} \mathrm{H}_{\mathrm{y}}$ & $\mathrm{ppm}$ & 186,1 & 121,4 & 217,0 & 4,04 \\
\hline Hydrogen chloride $\mathrm{HCl}$ & $\mathrm{ppm}$ & 0,5 & 0,5 & 0,5 & $\overline{---}$ \\
\hline Methane $\mathrm{CH}_{4}$ & $\mathrm{ppm}$ & 129,5 & 90,3 & 157,5 & --- \\
\hline Ethane $\mathrm{C}_{2} \mathrm{H}_{6}$ & $\overline{\mathrm{ppm}}$ & 0,7 & 0,6 & 1,1 & $\overline{---}$ \\
\hline Propane $\mathrm{C}_{3} \mathrm{H}_{8}$ & ppm & 4,0 & 1,6 & 2,9 & --- \\
\hline Ethylene $\mathrm{C}_{2} \mathrm{H}_{4}$ & $\mathrm{ppm}$ & 10,6 & 4,3 & 12,5 & --- \\
\hline Hexane $\mathrm{C}_{6} \mathrm{H}_{14}$ & $\mathrm{ppm}$ & 1,2 & 1,1 & 2,0 & --- \\
\hline Formaldehyde $\mathrm{CHOH}$ & $\mathrm{ppm}$ & 5,0 & 4,5 & 5,4 & --- \\
\hline Acetylene $\mathrm{C}_{2} \mathrm{H}_{2}$ & $\mathrm{ppm}$ & 13,0 & 3,4 & 9,7 & --- \\
\hline Acetic acid $\mathrm{C}_{2} \mathrm{H}_{4} \mathrm{O}_{2}$ & $\mathrm{ppm}$ & 3,6 & 2,9 & 4,9 & --- \\
\hline Methanol $\mathrm{CH}_{4} \mathrm{O}$ & $\mathrm{ppm}$ & 0,7 & 0,6 & 0,8 & --- \\
\hline Acetaldehyde $\mathrm{C}_{2} \mathrm{H}_{4} \mathrm{O}$ & $\mathrm{ppm}$ & 0,3 & 0,2 & 0,3 & $\begin{array}{cc}-- \\
\end{array}$ \\
\hline Benzene $\mathrm{C}_{6} \mathrm{H}_{6}$ & $\mathrm{ppm}$ & 3,3 & 0,9 & 4,5 & --- \\
\hline Styrene $\mathrm{C}_{8} \mathrm{H}_{8}$ & $\mathrm{ppm}$ & 2,8 & 1,1 & 3,1 & --- \\
\hline Ethanol $\mathrm{C}_{2} \mathrm{H}_{6} \mathrm{O}$ & ppm & 7,4 & 1,5 & 4,6 & --- \\
\hline Propene $\mathrm{C}_{3} \mathrm{H}_{6}$ & ppm & 1,3 & 0,6 & 3,7 & --- \\
\hline Propionaldehyde $\mathrm{C}_{3} \mathrm{H}_{6} \mathrm{O}$ & $\mathrm{ppm}$ & 0,3 & 0,2 & 0,4 & --- \\
\hline Acrolein $\mathrm{C}_{3} \mathrm{H}_{4} \mathrm{O}$ & ppm & 0,4 & 0,3 & 0,4 & --- \\
\hline Formic acid $\mathrm{CH}_{2} \mathrm{O}$ & ppm & 1,0 & 0,6 & 1,4 & --- \\
\hline Hydrogen cyanide $\mathrm{HCN}$ & $\mathrm{ppm}$ & 6,3 & 6,2 & 6,4 & --- \\
\hline
\end{tabular}

The $\mathrm{HF}$ and $\mathrm{C}_{7} \mathrm{H} 8$ gaseous compounds were not found at quantities exceeding detection limits.

Based on the obtained results it was found, that different positions of the secondary air intake has influence on concentrations of $\mathrm{CO}_{2}, \mathrm{O}_{2}, \mathrm{CO}, \mathrm{SO}_{2} \mathrm{NH}_{3}, \mathrm{CH}_{4}$, and other unburned hydrocarbons, however influence on concentrations of $\mathrm{NO}_{\mathrm{x}}$ and $\mathrm{HCN}$ were not observed. It was determined, that the most suitable position is when the height ratio of the chamber and the secondary air intake is 2.3 , that is the $\mathrm{X} / \mathrm{H} 2$ position. The $\mathrm{CO}$ concentrations are $25 \%$ lower in this position than in other positions, and $\mathrm{C}_{\mathrm{x}} \mathrm{H}_{\mathrm{y}}$ concentrations are $34 \%$ lower than at $\mathrm{X} / \mathrm{H} 1$ height, and even $44 \%$ lower than at $\mathrm{X} / \mathrm{H} 3$ height. Although authors [17] have determined, that in their case, change of position of the secondary air intake resulted in decrease of $\mathrm{NO}_{\mathrm{x}}$ concentration of approximately $10 \%$, however concentration of $\mathrm{CO}$ increased by as much as 7 times, thus it can be concluded, that in our case all positions of secondary air intake were at sufficiently good locations. Table 5 also gives average values of other resulting components, such as $\mathrm{SO}_{2}, \mathrm{NH}_{3}, \mathrm{HCl}, \mathrm{HF}, \mathrm{HCHO}, \mathrm{CH}_{4}$ and other unburned hydrocarbons $\mathrm{C}_{\mathrm{x}} \mathrm{H}_{\mathrm{y}}$.

$\mathrm{CO}$ and $\mathrm{C}_{\mathrm{x}} \mathrm{H}_{\mathrm{y}}$ are produced dues to different presence duration of these elements in the appropriate combustion phase. When the secondary air is at the lowest position $(\mathrm{X} / \mathrm{H} 1)$, the resulting $\mathrm{CO}$ and $\mathrm{C}_{\mathrm{x}} \mathrm{H}_{\mathrm{y}}$ compounds instantly fall into the secondary zone intake and therefore they stay at appropriate conditions for a shorter period of time.
When the secondary air intake channels are at the highest position (H3), the $\mathrm{CO}$ and $\mathrm{C}_{\mathrm{x}} \mathrm{H}_{\mathrm{y}}$ compounds detached from the fuel first move into the colder zone, and only then into the secondary air intake zone, where the temperature is not as high, compared to air supply channels at lower positions.

Table 6

Test results

\begin{tabular}{|l|c|c|c|c|c|}
\hline $\begin{array}{l}\text { Measured and calcu- } \\
\text { lated parameters }\end{array}$ & Unit & $\mathrm{X} / \mathrm{H} 1$ & $\mathrm{X} / \mathrm{H} 2$ & $\mathrm{X} / \mathrm{H} 3$ & $\begin{array}{c}\text { The ex- } \\
\text { panded } \\
\text { uncer- } \\
\text { tainty, } \%\end{array}$ \\
\hline Efficiency & $\%$ & 79,7 & 79,2 & 78,5 & $2,62 \%$ \\
\hline $\begin{array}{l}\text { Thermal losses in } \\
\text { flue gas }\end{array}$ & $\%$ & 18,6 & 19,4 & 19,7 & --- \\
\hline Chemical losses & $\%$ & 1,23 & 0,96 & 1,3 & --- \\
\hline $\begin{array}{l}\text { Heat losses due to } \\
\text { unburnt constituents }\end{array}$ & $\%$ & 0,5 & 0,5 & 0,5 & --- \\
\hline Nominal heat output & $\mathrm{kW}$ & 6,54 & 6,53 & 6,26 & $2,70 \%$ \\
\hline Flue gas temperature & ${ }^{\circ} \mathrm{C}$ & 281 & 281 & 275 & $1,4{ }^{\circ} \mathrm{C}$ \\
\hline $\begin{array}{l}\text { combustion chamber } \\
\text { temperature }\end{array}$ & ${ }^{\circ} \mathrm{C}$ & 621 & 648 & 601 & $1,8^{\circ} \mathrm{C}$ \\
\hline Draft & $\mathrm{Pa}$ & 10,53 & 11,23 & 10,05 & $2 \mathrm{~Pa}$ \\
\hline The test duration & $\mathrm{min}$ & 156 & 156 & 159 & --- \\
\hline Fuel amount & $\mathrm{kg}$ & 4,63 & 4,66 & 4,6 & $12 \mathrm{~g}$ \\
\hline Fuel consumption & $\mathrm{kg} / \mathrm{h}$ & 1,78 & 1,79 & 1,74 & --- \\
\hline
\end{tabular}

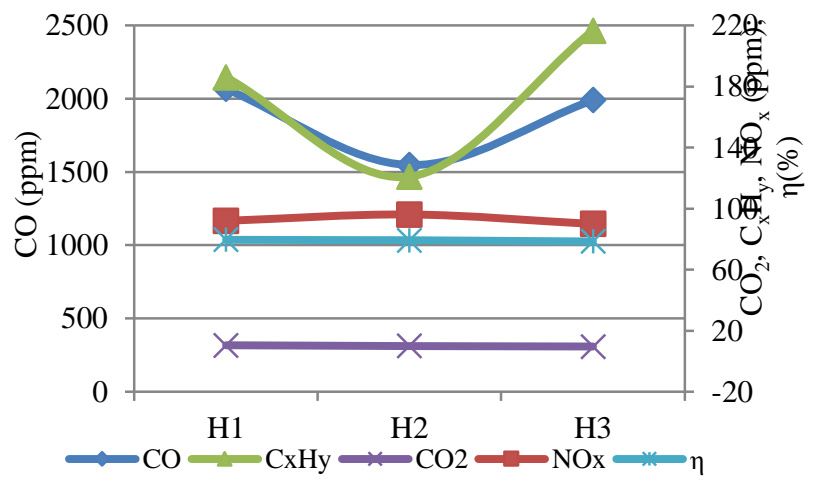

Fig. 10 Comparison of concentrations of emissions of $\mathrm{CO}$, $\mathrm{CO}_{2}, \mathrm{C}_{\mathrm{x}} \mathrm{H}_{\mathrm{y}}$ and $\mathrm{NO}_{\mathrm{x}}$, and coefficients of efficiency at various height of secondary air intake channels

\section{Conclusions}

1. When using vermiculite (V1) of lower thermal conductivity, the concentration of carbon monoxide (CO) decreased by approximately $30 \%$, and the concentration of hydrocarbons $\left(\mathrm{C}_{\mathrm{x}} \mathrm{H}_{\mathrm{y}}\right)$ decreased by half. Use of vermiculate of lower thermal conductivity resulted in an increase of temperature at the combustion chamber of $33^{\circ} \mathrm{C}$ and production of $25 \%$ more nitrogen oxides $\left(\mathrm{NO}_{\mathrm{x}}\right)$.

2 . It was determined, that height ratio of the chamber and the secondary air intake of $2.3(\mathrm{X} / \mathrm{H} 2)$ is the best secondary air intake position. In this position the concentrations of carbon monoxide (CO) is $25 \%$ lower, than in other positions, and concentrations of hydrocarbons $\left(\mathrm{C}_{\mathrm{x}} \mathrm{H}_{\mathrm{y}}\right)$ are $34 \%$ lower than at height ratio of $2(\mathrm{X} / \mathrm{H} 3)$, and even $40 \%$ lower, than at the ratio of 2.7 . 


\section{References}

1. Available from Internet: http://ec.europa.eu/geninfo/legal_notices_en.htm.

2. Eurostat 2014. Energy balance sheets 2011-2012. Energy Balanc. sheets 79.

3. Sturc, M. 2012. Renewable energy - Analysis of the latest data on energy from renewable sources. Eurostat - Stat. Focus 1-8.

4. Golovanova, N. 2015. Energy Balance 2014 (Lithuanian). Energy Balanc. 2014.

5. Brunner, T.; Obernberger, I. 2009. Primary measures for low-emission residential wood combustion comrarison old with optimesed modern systems, in Proc. 17th Eur. Biomass Conf. Exhib. 1-6.

6. Hartmann, H.; Turowski, P.; Obernberger, I.; Biedermann, F.; Brunner, T. 2012. Low emission operation manual for chimney stove users, 1-23.

7. Koyuncu, T.; Pinar, Y. 2007. The emissions from a space-heating biomass stove, Biomass and Bioenergy 31(1): 73-79. http://dx.doi.org/10.1016/j.biombioe.2006.06.014.

8. Williams, A.; Jones, J.; Ma, L.; Pourkashanian, M. 2012. Pollutants from the combustion of solid biomass fuels, Prog. Energy Combust. Sci. 38: 113-137. http://dx.doi.org/10.1016/j.pecs.2011.10.001.

9. Ndiema, C.K.W.; Mpendazoe, F.M.; Williams, A. 1998. Emission of pollutants from a biomass stove, Energy Convers. Manag. 39: 1357-1367. http://dx.doi.org/10.1016/S0196-8904(98)00008-9.

10. Fine, P.M.; Cass, G.R.; Simoneit, B.R.T. 2001. Chemical characterization of fine particle emissions from fireplace combustion of woods grown in the northeastern United States, Environ. Sci. Technol. 35: 2665-2675.

http://dx.doi.org/10.1021/es001466k.

11. Hrdlicka, J.; Skopec, P.; Dlouhy, T.; Hrdlicka, F. 2015. Emission factors of gaseous pollutants from small scale combustion of biofuels, Fuel 165: 68-74. http://dx.doi.org/10.1016/j.fuel.2015.09.087.

12. Vassilev, S.V.; Baxter, D.; Andersen, L.K.; Vassileva, C.G. 2010. An overview of the chemical composition of biomass, Fuel 89: 913-933. http://dx.doi.org/10.1016/j.fuel.2009.10.022.

13. LST EN 13240 Roomheaters fired by solid fuel Requirements and test methods, 2015.

14. Roy, M.M.; Corscadden, K.W. 2012 An experimental study of combustion and emissions of biomass briquettes in a domestic wood stove, Appl. Energy 99: 206-212. http://dx.doi.org/0.1016/j.apenergy.2012.05.003.

15.Shah, R.; Date, A.W. 2011. Steady-state thermochemical model of a wood-burning cook-stove, Combust. Sci. Technol. 183: 321-346. http://dx.doi.org/10.1080/00102202.2010.516617.

16. Mitchell, E. J. S. et al. 2016. The impact of fuel properties on the emissions from the combustion of biomass and other solid fuels in a fixed bed domestic stove, Fuel Process. Technol. 142: 115-123. http://dx.doi.org/10.1016/j.fuproc.2015.09.031.

17. Liu, H.; Chaney, J.; Li, J.; Sun, C. 2013. Control of NOx emissions of a domestic/small-scale biomass pellet boiler by air staging, Fuel 103: 792-798. http://dx.doi.org/10.1016/j.fuel.2012.10.028.

18. Loo, S.V.; Koppejan, J. 2008. The Handbook of Biomass Combustion and Co-firing, Earthscan: London, UK, 464 p. http://dx.doi.org/10.1007/s13398-014-0173-7.2.

19. Ghafghazi, S.; Sowlati, T.; Sokhansanj, S.; Bi, X.; Melin, S. 2011.Particulate matter emissions from combustion of wood in district heating applications, Renew. Sustain. Energy Rev. 15: 3019-3028. http://ddx.oi.org/10.1016/j.rser.2011.04.001.

20. Glarborg, P. 2003. Fuel nitrogen conversion in solid fuel fired systems, Prog. Energy Combust. Sci. 29: 89113.

http://dx.doi.org/10.1016/S0360-1285(02)00031-X.

\section{T. Vonžodas, N. Pedišius, A. Džiugys}

\section{RESEARCH OF FACTORS INFLUENCING THE BURNOUT QUALITY INSIDE A BIOMASS COMBUSTION CHAMBER}

S u m m a r y

For purposes of this research the most common type of combustion chamber structure was selected - combustion chamber of primary and secondary air channel system. A wide variety of gaseous compounds (such as carbon monoxide $(\mathrm{CO})$, carbon dioxide $(\mathrm{CO} 2)$, nitrogen dioxides (NOx), sulphur dioxide (SO2), ammonia (NH3), hydrogen chloride $(\mathrm{HCl})$, hydrogen fluoride $(\mathrm{HF})$, formaldehyde (HCHO), methane ( $\mathrm{CH} 4)$ and other un-burned hydrocarbons (CxHy)) was measured using an FTIR spectrometer. Other subjects measures obtained were particulate matter (PM), temperature inside the combustion chamber, smoke flue draught, etc., including chemical composition of the fuel. It was determined, that the burnout quality of the combustion chamber was influenced both by combustion chamber walls of different thermal conductivity and by position of the secondary air intake. It was determined, that use of vermiculite of lower thermal conductivity (V1) reduced the $\mathrm{CO}$ concentration by approximately $30 \%$, and the general concentration of all volatile organic compounds (CxHy) was reduced by half, also resulting in increase of temperature inside the combustion chamber by $33^{\circ} \mathrm{C}$ and a $25 \%$ increase of nitrogen oxides (NOx). It was also determined that the height ratio of the combustion chamber and the secondary air intake of $2.3(\mathrm{X} / \mathrm{H} 2)$ is the most suitable position for the secondary air intake. This position ensures a carbon monoxide $(\mathrm{CO})$ concentration is $25 \%$ lower than in other positions, and the concentration of all volatile organic compounds ( $\mathrm{CxHy}$ ) is $34 \%$ lower than at height ration of $2.7(\mathrm{X} / \mathrm{H} 1)$, and even $44 \%$ lower than at height ratio of 2 .

Keywords: biomass stove; combustion and emissions; efficiency.

Received January 12, 2016 Accepted February 06, 2017 